\title{
Message from President
}

\section{Pradeep Seth}

(C) Indian Virological Society 2010

Indian Virological Society (IVS) is publishing Indian Journal of Virology (INJV) since 1985. The Journal got a face lift during 2005. In 2010, IVS developed a partnership with Springer India Pvt. Ltd. for co-publishing the Journal to facilitate its worldwide circulation. I am pleased to see that now INJV has evolved in its new image with modern features. INJV is a unique journal in the Asian continent that provides rapid publication opportunity on research findings on all aspects of viruses affecting major host species relating to mankind.

I hope the Journal will be useful to a large section of people associated with Agriculture, Fisheries, Medical and Veterinary science.

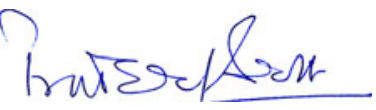

P. Seth $(\bowtie)$

President,

Indian Virological Society, Office Block NASC Complex,

P.O. Box 11318, New Delhi 110012, India 